Syntax Literate : Jurnal Ilmiah Indonesia p-ISSN: 2541-0849

e-ISSN : 2548-1398

Vol. 4, No. 9 September 2019

\title{
DINAMIKA POLITIK DAERAH DALAM PELAKSANAAN SISTEM PEMILU UMUM LEGISLATIF DAERAH
}

\section{Fadhillah Harnawansyah}

Fakultas Ilmu Sosial dan Ilmu Politik, Universitas Musi Rawas Sumatera Selatan

Email: mfadhillah@fisip-unmura.com

\begin{abstract}
Abstrak
Dalam dinamika politik daerah dan sistem pemilihan umum legislatif daerah (Pilegda) saat ini ditemukan permasalahan adanya kondisi yang tidak harmoni antara format sistem Pilegda dengan format sistem pemerintahan daerah (Pemda), sehingga menimbulkan rendahnya perwakilan politik masyarakat daerah oleh legislatornya. Penelitian ini sebagai studi perbandingan pelaksanaan Sistem Pemilu Daerah (Pilegda) di Kabupaten Musi Rawas, Kota Lubuklinggau dan Kabupaten Musi Rawas Utara. Penelitian ini memberikan kontribusi secara luas untuk memperoleh pengetahuan tentang dinamika politik daerah dan sistem Pilegda yang ideal dan harmoni dengan sistem Pemda, yang dapat digunakan di masa depan; dengan tingkat keterwakilan politik yang tinggi, serta untuk mengetahui faktor-faktor apa saja yang berhubungan dengan sistem Pilegda tersebut. Penelitian ini menggunakan metode kualitatif deskriptif, dengan menggunakan teknik pengumpulan data melalui wawancara secara mendalam, observasi partisipan langsung, dan dokumentasi; agar dapat memberikan data yang lebih akurat dan mendalam. Dalam kajian ini, peneliti melakukan proses analisis data dengan metode triangulasi, baik dari informan dan dokumentasi, maupun observasi langsung untuk melakukan verifikasi data. Hasil penelitian menunjukkan bahwa: Pilegda yang ideal dengan sistem Pemda saat ini adalah sistem Pilegda model semi-distrik. Kemudian, peneliti juga menyimpulkan bahwa secara politis, sistem Pilegda dan sistem Pemda saat ini masih belum harmoni. Oleh karena itu, perbaikan sistem ini harus didukung juga oleh penyelenggaraan Pilegda yang berkualitas, berintegritas, profesional, jujur, dan adil; sehing ga akan melahirkan legislator daerah yang memiliki tingkat keterwakilan politik yang tinggi terhadap konstituennya; dan sekaligus dapat efektif dalam penyelenggaraan Pemda.
\end{abstract}

Kata Kunci: Dinamika Politik Daerah \& Sistem Pilegda.

\section{Pendahuluan}

Pemerintahan yang kuat adalah pemerintahan yang dapat dukungan penuh dari rakyatnya. Oleh karna itu sebagai wujud terimakasih atas dukungan rakyat tersebut 
sudah sepantasnya pemerintah melalui aparatur birokrasi memberikan pelayanan dengan sebaik-baiknya kepada masyarakat (Misbak, 2018).

Dewan Perwakilan Rakyat Daerah merupakan lembaga perwakilan rakyat daerah yang berkedudukan sebagai unsur penyelenggara pemerintahan daerah. Di sini Peran DPRD dalam proses pemilihan keanggotaannya dipilih secara periodik setiap lima tahun sekali. Dalam rangka pemilihan anggota DPRD tersebut, diselenggarakan melalui pemilihan umum legislatif daerah (Pilegda), di mana Pilegda tersebut merupakan bagian dari penyelenggaraan pemilihan umum legislatif secara keseluruhan karena diselenggarakan secara bersamaan dan serentak di seluruh wilayah Negara Kesatuan Republik Indonesia.

Dalam kehidupan politik saat ini, Undang-Undang Dasar 1945 telah menjadi konstitusi yang lebih demokratis atau lebih dikenal sebagai demokrasi konstitusional. Oleh karena itu, sistem pemilihan umum (Pemilu) yang kita anut dalam membangun bangsa, merujuk pada konsep demokrasi konstitusional tersebut sehingga dalam proses pergantian kepemimpinan nasional sudah diatur kebijakannya di dalam peraturan perundang-undangan yang menjadi pedoman dalam penyelenggaraan pemilu setiap lima tahun sekali dan diselenggarakan oleh penyelenggara Pemilu yaitu Komisi Pemilihan Umum (KPU), Badan Pengawas Pemilu (Banwaslu), dan Dewan Kehormatan Penyelenggara Pemilu (DKPP) sebagai komisi etik.

Dalam pelaksanaan Pemilu legislatif di Indonesia terbagi ke dalam pemilu legislatif untuk memilih Dewan Perwakilan Rakyat Republik Indonesia (DPR-RI), Dewan Perwakilan Daerah Republik Indonesia (DPD-RI), dan Dewan Perwakilan Rakyat Daerah Provinsi (DPRD Provinsi) serta Dewan Perwakilan Rakyat Daerah Kabupaten/Kota (DPRD Kabupaten/Kota). Pemilu legislatif ini yang menjadi pesertanya adalah partai politik dengan mencalonkan para calon anggota legislatif (DPR/DPRD).

Kemudian dalam pelaksanaan Pemilu saat ini terjadi fenomena-fenomena, contohnya: di mana sejak Pemilu dilaksanakan sejak tahun 1955 sampai dengan tahun 2014, kelemahan-kelemahan sistem proporsional dalam Pemilu legislatif juga disampaikan oleh Nizam (2015: 4) yang menyatakan bahwa:

Evaluasi yang dilakukan terhadap penyelenggaraan pemilu yang telah dilaksanakan. Di mana pemilu pertama kalinya yang di mulai tahun 1955 
sampai dengan pemilu 9 April 2014 yang pelaksanaannya masih banyak terdapat kekurangan dan kelemahan.

Selanjutnya dalam pelaksanaan Pemilu di daerah terjadi fenomena yang berkaitan dengan "money politics" dan "high cost" dalam politik seperti yang digambarkan oleh (Haris, 2005) dalam bukunya Pemilu Langsung di Tengah Oligarki Partai, bahwa:

Berbagai hasil survey, Polling dan penelitian yang pernah dilakukan terhadap partai politik dan lembaga legislatif memperlihatkan merosotnya tingkat kepercayaan publik, terutama terhadap partai-partai besar yang berkuasa, baik di legislatif maupun eksekutif. Merosotnya kepercayaan publik terhadap partai, melainkan juga karena kecenderungan meningkatnya fenomena politik uang (money politics) dalam relasi legislatif-eksekutif, terutama di tingkat lokal.

Berdasarkan fenomena-fenomena di atas terlihat perbedaan permasalahan yang menjadi fokus penelitian ini, di mana peneliti menfokuskan penelitian ini untuk mencari suatu format sistem Pemilu legislatif daerah yang harmonis dengan format sistem pemerintahan daerah; dimana diharapkan dapat menimbulkan dampak meningginya tingkat perwakilan politik masyarakat daerah oleh para legislatornya.

Menurut peneliti, pengertian tentang dinamika politik daerah adalah adanya peristiwa perubahan dan perkembangan fenomena-fenomena politik yang terjadi di daerah dan/atau pemerintahan daerah. Dinamika kejadian atau fenomena politik yang terjadi di daerah tersebut banyak ragamnya mulai daerah pemilihan umum kepala daerah, pemilihan kepala desa, pemilihan umum legislatif daerah, dan lain sebagainya.

Pada penelitian ini tentunya akan menfokuskan kajian hanya pada dinamika pemilihan umum legislatif daerah khususnya pada studi perbandingan mengenai pelaksanaan sistem pemilihan umum legislatif daerah pada Kabupaten Musi Rawas, Kota Lubuklinggau dan Kabupaten Musi Rawas Utara; berkaitan dengan harmonisasi sistem pemilihan umum legislatif daerah dengan sistem pemerintahan daerah, dan dengan tingkat perwakilan politik masyarakat terhadap legislatornya.

Banyak konsep yang berkaitan dengan pemilihan umum, namun pengertian umum dari sistem pemilihan umum menurut Budiardjo (2008: 461) bahwa dalam kajian ilmu politik telah dikenal bermacam-macam sistem pemilihan umum dengan berbagai variasinya, akan tetapi pada umumnya ada dua prinsip pokok, yaitu:

a. Single-member Constituency (satu daerah pemilihan atau wilayah distrik memilih satu wakil; biasanya disebut Sistem Distrik ). 
b. Multi-member Constituency (satu daerah pemilihan memilih beberapa wakil; biasanya dinamakan Sistem Perwakilan Berimbang atau Sistem Proporsional).

Kemudian konsep sistem pemilu juga dikemukakan oleh Duverger (dalam Grofman dan Lijphart, 2003: 4) mengatakan bahwa:

All three articles take as their starting point the formulation in Duverger (1951a) that the plurality system favors the two-party system, commonly referred to as "Duverger's Law", while PR methode and the double-ballot system favor multipartyism, referred to as "Duverger's Hypothesis

Dalam perkembangannya pada tahun 1950 di Kongres Internasional Ilmu Politik, (Duverger \& Stevenson, 1955) mengemukakan tentang tiga rumus atau tiga hukum dasar, yaitu:

(1) Propotional representation tends to lead to the formation of many independent parties; (2) The two-ballot majority system tends to lead to the formation of many parties that are allied with each other; (3) The plurality rule tends to produce a two-party system.

Secara umum, konsep sistem pemilihan umum yang dikenal ada 2 model utama adalah sistem distrik (single-member contituency) dan sistem proporsional (multimember constituency) (Duverger \& Stevenson, 1955). Namun sangat berbeda sistem pemilihan umum yang digunakan di Indonesia dan beberapa negara di dunia, yaitu sistem campuran antara sistem distrik dan sistem proporsional, yaitu sistem proporsional terbuka.

Sistem distrik merupakan sistem pemilihan umum paling tua dan didasarkan pada kesatuan geografis (wilayah), di mana setiap kesatuan geografis atau wilayah dinamakan distrik, karena kecilnya daerah yang tercakup maka memperoleh satu kursi dalam parlemen. Di mana distrik merupakan satu wilayah kecil (distrik pemilihan) memilih satu wakil tunggal (single-member contituency) dengan konsep dasar pluralitas (suara terbanyak).

Sedangkan di Indonesia, menggunakan sistem proporsional dengan daftar calon terbuka atau sistem proporsional terbuka adalah suatu sistem untuk memilih anggota DPR dan DPRD adalah sistem di mana penentuan pemenang Pemilu di suatu daerah pemilihan didasarkan pada perolehan kursi partai politik yang bersangkutan dan penghitungan hasil bagi suara sah partai politik yang bersangkutan dengan Bilangan Pembagi Pemilih (BPP). Sementara maksud daftar calon terbuka, bahwa pada waktu pencalonan, kepada partai politik diberi kesempatan untuk menetapkan nama-nama 
calon dengan kualifikasi terbaik sebanyak jumlah kursi yang dialokasikan di daerah pemilihan.

Menurut peneliti pada saat ini pengertian tentang sistem Pemilu legislatif daerah di sini memiliki pengertian yang sama dengan sistem Pemilu legislatif di atas. Namun pemaknaan kata "Daerah" di sini memiliki makna yang sama dengan "daerah" dalam pemerintahan daerah, yaitu sebagaimana dijelaskan oleh (Wajong, 1975) dalam bukunya Azas dan Tujuan Pemerintahan Daerah, menjelaskan bahwa Alam pikiran di masa Revolusi Perancis yang merumuskan "gemeente" (Daerah-Kota Otonom) sebagai "Suatu persekutuan penduduk yang disatukan oleh hubungan setempat/sedaerah" (Une societe de citoyens, unis par des relations locales).

Sesungguhnya Pemilu, sesuai dengan Undang Undang nomor 8 tahun 2012 tentang pemilihan umum pada pasal 3 dan 5 memiliki maksud dan tujuan penyelenggaraannya, yaitu:

a. Memilih wakil rakyat yang duduk dalam lembaga perwakilan rakyat baik tingkat pusat, wilayah maupun daerah (DPR-RI, DPRD Propinsi dan DPRD Kabupaten/Kota).

b. Memilih wakil rakyat yang duduk dalam lembaga perwakilan daerah (DPD RI);

c. Membentuk pemerintahan yang demokratis, kuat serta memperoleh dukungan sebesar-besarnya dari rakyat (Legitimate); Menurut Aurel Croissant (dalam (Riwanto, 2016)).

Dalam perkembangannya, konsep tentang sistem pemerintahan mengalami pergeseran di mana dikenal pula sistem pemerintahan campuran. Hal ini sebagaimana diuraikan oleh (Achmad \& Rudianto, 2012) dalam bukunya yang berjudul Tata Kelola Bernegara dalam Perspektif Politik menjelaskan bahwa sistem pemerintahan campuran, merupakan upaya mencari jalan tengah untuk mengambil yang terbaik dari sistem parlementer dan presidensial. Dalam praktiknya, ada dua model sistem pemerintahan campuran yaitu sentralisasi dan desentralisasi. Model sistem pemerintahan campuran ini, contohnya ada dua. Pertama, model campuran sentralisasi yaitu di negara Perancis; Kedua, model campuran desentralisasi dengan konsep otonomi daeah yaitu di negara Indonesia.

Berdasarkan prinsip-prinsip itu, maka sistem pemilihan umum legislatif daerah yang harmoni dengan sistem pemerintahan daerah, serta sistem-sistem lainya (seperti 
sistem politik, sistem kepartaian, dan sistem sosial budaya), merupakan suatu "keharusan" agar efektifitas pemilu dapat tercapai. Kemudian dengan sistem yang harmoni juga diharapkan dapat meningkatkan tingkat keterwakilan politik masyarakat yang tinggi antara legislator dengan konstituennya.

\section{Gambar 1. Sistem Pemilihan Umum Legislatif Daerah}

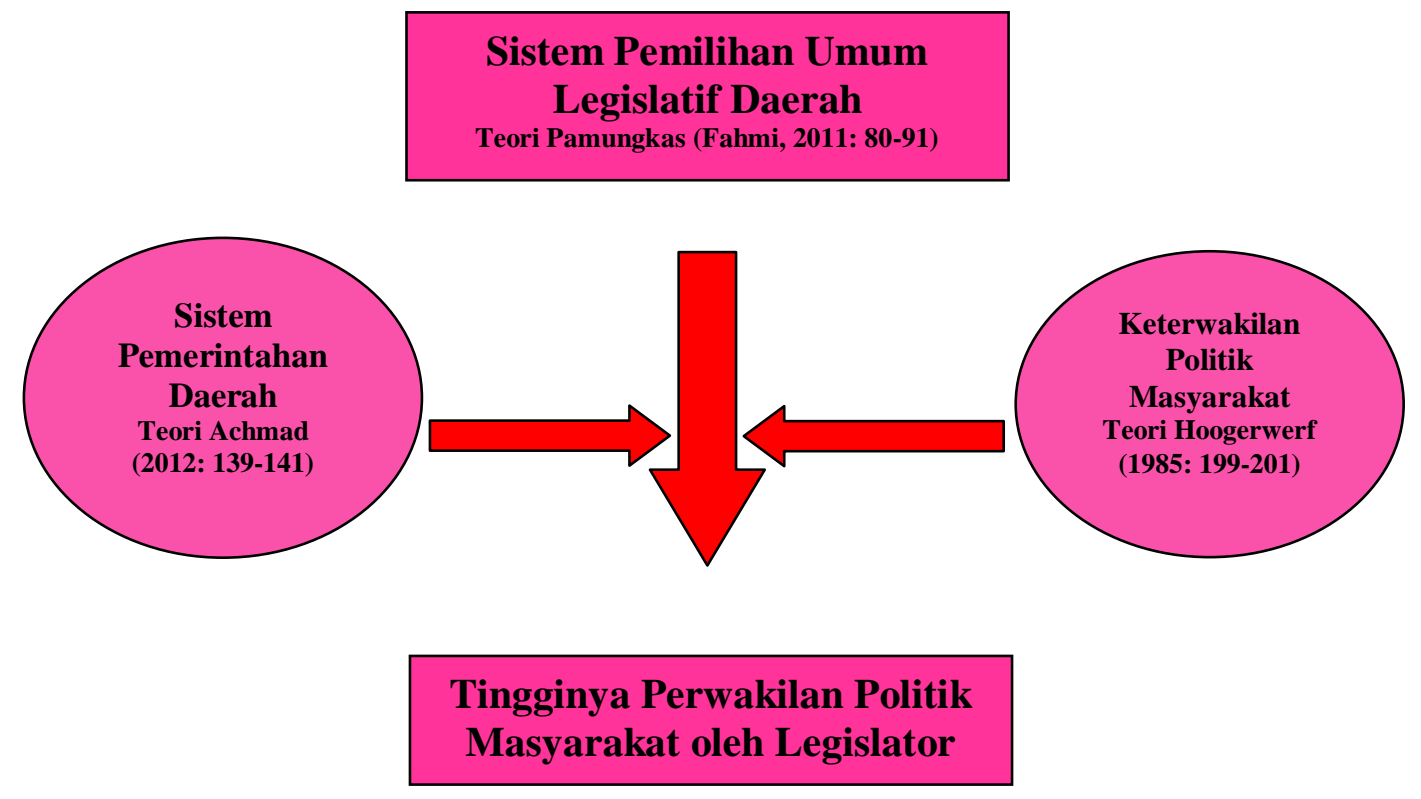

\section{Metode Penelitian}

Desain yang digunakan dalam penelitian ini adalah penelitian secara kualitatif dengan metode deskriptif. Pemilihan pendekatan kualitatif dengan pertimbangan penelitian ini diharuskan menggali dan mengumpulkan informasi dan fakta dari informan, tentang dinamika politik daerah dan pemilihan umum legislatif daerah, khususnya tentang perbandingan pelaksanaan sistem Pemilu legislatif daerah (Pilegda) yang digunakannya saat ini di kabupaten Musi Rawas, kota Lubuklinggau, dan kabupaten Musi Rawas Utara, mulai proses penerapannya hingga output yang dihasilkan oleh sistem tersebut.

Oleh karena itu, peneliti diwajibkan untuk menyerap pandangan menurut informan itu sendiri dengan cara mengumpulkan data berupa cerita rinci dari informan yang diungkapkannya apa adanya, sesuai dengan bahasa dan pandangan informan. Untuk mencapai tingkat validitas data yang tinggi, maka peneliti harus memberikan 


\section{Fadhillah Harnawansyah}

kesempatan yang seluas-luasnya kepada informan untuk menjelaskan fenomena, proses, dan dampak dari dinamika politik daerah dan penerapan sistem pemilihan umum legislatif daerah yang digunakan saat ini, sehingga informasi dan aspirasi informan dapat terungkap secara lengkap dan holistik.

Kemudian data hasil penelitian tersebut dilakukan uji validasi dengan triangulasi data, dan selanjutnya diolah dan dianalisis secara sistematis dan terstruktur dengan kajian teori politik, yang mampu memberikan hasil kajian yang mendalam, kritis, obyektif, dan substantif.

\section{Hasil Penelitian dan Pembahasan}

Peneliti melihat bahwa dinamika politik daerah di ketiga daerah penelitian sudah berjalan cukup dinamis, walaupun masih jauh dari harapan kita bersama dalam upaya membangun demokrasi yang berkualitas dan bertanggungjawab. Namun, apabila kita tinjau dari sudut pandang stabilitas politik daerah, sudah baik, di mana segala proses Pemilu legislatif dan Pemilu kepala daerah telah berjalan dengan baik, lancar dan damai serta tetap menjunjung tinggi asas Pemilu yaitu Luber Jurdil, termasuk juga harapan terwujudnya penyelenggara Pemilu yang profesional dan berintegritas.

\section{a. Model Penyuaraan}

Pada tiga wilayah penelitian diatas, terlihat bahwa model penyuaraan dari setiap pemilih/konstituen tidak terjadi kendala serius dan tidak terjadi perbedaan pelaksanaannya oleh KPU di ketiga wilayah penelitian. Memang, model sekarang ini cukup membingungkan dan rumit bagi masyarakat yang berpendidikan rendah. Oleh karena itu, diperlukan suatu metode yang lebih praktis dalam melakukan pilihan tersebut. Banyaknya kertas suara yang harus dipilih oleh masyarakat cukup membuat kebingungan masyarakat dalam melakukan pilihan, hal ini disebabkan mereka tidak/terlalu mengenal Caleg yang mencalonkan diri, terlebih banyaknya calon dari masing-masing kertas suara.

Hal ini dapat disederhanakan dengan memperbaiki sistem dan metode dalam Pemilu legislatif pusat, provinsi dan kabupaten/kota. Secara sistem, diperbaiki sistem dengan model pencalonan setiap Dapil yang lebih sedikit calonnya, sehingga tidak membingungkan masyarakat. Kemudian secara metode, harusnya metode pencoblosan sudah mulai melakukan modifikasi dan pendidikan politik bagi 
masyarakat agar dapat memanfaatkan teknologi informasi, seperti: penggunaan elektronic voting (E-voting).

\section{b. Metode Pembagian Daerah Pemilihan (Dapil)}

Indikator besaran daerah pemilihan (Dapil) merupakan faktor utama dalam sistem Pemilu. Di sini akan terlihat apakah suatu sistem Pemilu akan ke distrik atau ke proporsional. Oleh karena itu, peneliti berkeyakinan bahwa bila Pilegda untuk lima tahun nanti harus melakukan perbaikan Dapil ini, atau dengan kata lain berpedoman konsep model semi-distrik yaitu wilayah Dapil adalah wilayah kecamatan saja; karena model ini mampu melahirkan legislator yang memiliki legitimasi lebih dari 66 persen suara sah pemilih, sehingga masih lebih tinggi dari tingkat legitimasi dalam perwakilan pada Pilkada, sehingga pada akhirnya berdampak pula pada peningkatan keterwakilan politik masyarakat terhadap legislatornya.

\section{c. Pembuatan Batas-batas Representasi}

Pembatasan terhadap pemilih dan kandidat tetap diperlukan dalam memenuhi kebutuhan/ketentuan dari pemerintahan, pembangunan dan demokrasi. Oleh karena itu, penguatan Parpol dan kaderisasi Parpol sangat diperlukan untuk meningkatkan kapasitas dan kapabilitas para Caleg. Tantangan global dan kebutuhan nasional dan lokal (daerah) selalu menjadi faktor utama dalam mengambil pertimbangan terhadap sebuah kebijakan publik. Hal ini diharapkan akan bermuara pada peningkatan kinerja DPRD dan efektifitas pemerintahan daerah dan kesejahteraan rakyat daerah.

\section{d. Metode Formula Pemilihan}

Pemberlakuan dan pelaksanaan model formula Pemilu yang ditetapkan oleh pemerintah dan KPU berlaku umum dan sama di ketiga lokasi penelitian, sehingga peneliti tidak menemukan perbedaan penerapanya di ketiga lokasi. Namun peneliti menemukan kritik dari para pelaku politik dan masyarakat bahwa model formula Pemilu saat ini perlu untuk dievaluasi, agar lebih sederhana dan lebih efisien serta efektif. Di sini peneliti mengusulkan perubahan dengan pola pluralistik untuk setiap Dapil dengan peringkat perolehan suara Parpol sesuai dengan jumlah kursi yang tersedia. Sesungguhnya, penggunaan formula perhitungan dengan model SLM ini 
sudah menuju proses kearah model perhitungan sistem semi-distrik. Hal ini menurut peneliti patut didukung kearah model pluralistik.

\section{e. Metode Ambang Batas}

Model ambang batas tidak berlaku di Pilegda, dan hal ini tidak ada perbedaan dalam pelaksanaannya di ketiga lokasi penelitian. Namun, model ambang batas untuk daerah dengan model sistem semi-distrik patut untuk dijadikan referensi dalam pengambilan kebijakan dan keputusan dalam Undang-Undang Pemilu di masa depan, sebab dalam model distrik tidak ada ambang batas parlemen, karena dalam setiap Dapil atau distrik yang mendapatkan kursi hanya Parpol yang mendapatkan suara terbanyak (pluralitas) sesuai jumlah kursi yang tersedia.

\section{f. Metode Penetapan Jumlah Kursi Legislatif Daerah}

Model penetapan besaran jumlah kursi DPRD dan DPR-RI saat ini perlu dilakukan penyesuaian kembali, di mana besaran jumlah penduduk dan luasan wilayah yang diwakili seorang anggota legislatif dapat menjadi pedoman dalam menentukan jumlah kursi perwakilan (DPRD) suatu daerah. Oleh karena itu, tepatlah bila pedoman ini tetap dilanjutkan berdasarkan luas wilayah kecamatan saja dan jumlah penduduk (distrik) agar nantinya anggota DPRD lebih fokus kepada konstituennya.

Berdasarkan persepsi politik masyarakat di dalam Pilegda bahwa sistem Pemilu legislatif daerah saat ini perlu dilakukan pembenahan terus-menerus untuk menuju ke sistem Pemilu legislatif daerah yang lebih ideal, efisien, dan efektif dalam menyelenggarakan pemerintahan daerah, yaitu dengan merubah sistem Pemilu legislatif daerah dari sistem proporsional terbuka menuju sistem semi-distrik. Hal ini tentunya diharapkan akan menghadirkan banyak keuntungan dalam kinerja DPRD dan keterwakilan politik masyarakat, serta memperkuat sistem pemerintahan daerah itu sendiri, dengan tidak melupakan prinsip-prinsip demokrasi dan sistem pemerintahan daerah.

\section{g. Presfektif Politik: Harmonisasi Sistem Pemilu Legislatif Daerah dengan}

\section{Sistem Pemerintahan Daerah}

Relevansi keterwakilan politik dengan efektivitas pemerintahan daerah saat ini akan sulit terwujud, apabila model keterwakilan politik yang masih mendua saat ini dengan model hubungan keterwakilan campuran (politico), antara keterwakilan 
politik terhadap masyarakat dan terhadap partai politik yang sangat dominan. Terlebih kapabilitas dan kapasitas para anggota DPRD masih di bawah harapan dan kebutuhannya dalam melaksanakan tugas dan fungsinya sebagai anggota DPRD yang masih banyak kendala.

Pemanfaatan teknologi informasi dalam politik sudah selayaknya dan secepatnya harus diterapkan oleh pemerintah dan penyelenggara Pemilu, agar pelaksanaan Pemilu di Indonesia dapat lebih efektif, efisien, akuntabel, transparan, dan profesional dalam mewujudkan demokrasi yang lebih baik di masa depan.

Secara umum, efektivitas pemerintahan daerah dapat tercapai dengan baik bila sistem Pemilu legislatif daerahnya harus selaras dengan menggunakan model perwakilan politik yang bersifat utusan atau delegate. Hal ini sangat mungkin dikarenakan model ini sangat menjamin tingkat keterwakilan politik legislator hanya kepada konstituennya sangat tinggi, namun memang terjadi pelemahan dalam keterwakilan terhadap partai politik.

Sistem Pilegda saat ini secara sistem sudah cukup baik, namun belum bisa memberikan kualitas dan loyalitas para legislator terhadap konstituennya dan atau Parpolnya masing-masing. Oleh karena itu, peneliti berkeyakinan bahwa dengan mengubah sistem Pilegda yang baik dan ideal akan lebih meningkatkan representasi politik masyarakat oleh legislator daerah, termasuk perbaikan regulasi dalam mengatasi kelemahan-kelemahan dalam SDM dan integritas para Caleg di masa yang akan datang.

Sesungguhnya otonomi daerah bertujuan untuk mempercepat pertumbuhan ekonomi dan pembangunan daerah, yang nantinya bermuara pada peningkatan kesejahteraan masyarakat di daerah tersebut. Sebenarnya, itulah inti dari otonomi daerah yang bersumber dari asas desentralisasi, misalnya daerah Kabupaten Musi Rawas diserahkanlah pengelolaan sumber daya alam, yang diharapkan sumber daya alam tersebut secara optimal dapat mendatangkan Pendapatan Asli Daerah (PAD) bagi daerah tersebut. Di mana nantinya pembagian keuntungannya dapat dibagi lebih banyak ke daerah, provinsi, dan juga pemerintah pusat, termasuk efek domino dari perkembangan daerah sekitar yang dijadikan pusat pemanfaatan sumber daya alam tersebut. 
Berdasarkan hal tersebut, menurut pendapat peneliti bahwa bukan berarti adanya otonomi daerah tersebut membuat daerah tidak ada lagi hubungan dengan pemerintah pusat. Hal inilah yang menjadikan pendapat yang salah, seperti dikatakan orang bahwa otonomi daerah itu melahirkan "raja-raja kecil" di daerah; hal ini merupakan pandangan yang sangat keliru. Kita dalam konteks NKRI, mulai dari bupati/walikota, gubernur, dan presiden merupakan rantai komando pemerintahan secara umum.

Oleh karena itu, hubungan antara daerah dengan provinsi, daerah dengan pemerintah pusat harus tetap berjalan sesuai dengan mekanisme dan peraturan perundang-undangan yang berlaku. Kemudian anggaran-anggaran di pemerintah pusat juga dipersiapakan untuk mempercepat pembangunan di daerah, yang berbentuk Dana Alokasi Khusus (DAK) dan Dana Alokasi Umum (DAU), serta sumber-sumber lain dari pendapatan yang sah.

Maka dari itu, kepala daerah kabupaten/kota dituntut oleh pemerintah pusat untuk melakukan inovasi di daerah untuk menggali sebanyak mungkin PAD mereka masing-masing. Dalam rangka untuk meningkatkan APBD mereka, tentunya hal ini dalam rangka untuk kemakmuran bagi seluruh masyarakat daerahnya. Akan tetapi, bukan berarti mereka meninggalkan hubungan baik dengan pemerintah provinsi dan pemerintah pusat, di dalam koridor NKRI.

Untuk itu, DPRD harus mampu bersinergi dengan pemerintah daerah, di mana sebaik apapun tekad kepala daerah/Pemda mau membangun daerah, kalau dukungan dari DPRD tidak optimal maka hasilnya tidak akan baik, contohnya: dalam pembuatan peraturan daerah (Perda) untuk melakukan penggalian/ ekspolarasi sumber daya alam daerah, tentunya diperlukan regulasi yang dibuat oleh Pemda yang disahkan oleh DPRD.

Kemudian dalam hal menyusun anggaran belanja, tentunya diperlukan persetujuan/pengesahan dari DPRD; jadi sinergi yang baik antara kepala daerah, DPRD, dan OPD merupakan hal yang paling menentukan keberhasilan dalam pelaksanaan otonomi daerah tersebut. Bukan berarti kepala daerah itu berjalan sendiri, tanpa memperhatikan DPRD; di mana berdasarkan Undang-Undang Nomor 23 tahun 2014 tentang Pemerintahan Daerah dinyatakan bahwa pemerintahan daerah adalah Kepala daerah dan DPRD. 
Berdasarkan fakta yang diuraikan di atas menunjukkan bahwa hubungan harmoni antara DPRD dan Kepala Daerah/OPD merupakan hubungan harmoni yang masih dipaksakan, dikarenakan akan menjadi penghambat bagi kinerja masing-masing. Sebenarnya, inilah yang dimaksudkan oleh teori sistem, bahwa apabila salah satu bagian dari sistem tidak berfungsi maka akan menghambat bagian lainnya dari sistem tersebut untuk bekerja secara baik.

Di sini menunjukkan bahwa kinerja dan hubungan yang harmoni antara DPRD dan kepala daerah saat ini adalah merupakan hasil kompromi dalam memperjuangkan kepentingan mereka masing-masing. Hal ini akan berdampak positif apabila tujuan mereka tetap sama untuk kepentingan rakyat daerah; namun sebaliknya bila mereka hanya memperjuangkan kepentingan pribadi dan ambisi politik masing-masing, maka akan menghasilkan pemerintahan yang tidak sesuai dengan aspirasi rakyat daerahnya.

Berdasarkan uraian di atas, peneliti melihat suatu simpulan sementara bahwa sistem Pemilu yang digunakan saat ini masih perlu dilakukan perubahan yang cukup mendasar agar bisa memenuhi keseimbangan sistem antara sistem Pemilu legislatif daerah dengan sistem pemerintahan daerah, yang berpedoman pada tingkat perwakilan politik di DPRD yang sangat tinggi hubungannya dengan konstituennya, yaitu dengan sistem Pilegda yang semi-distrik.

Kondisi ideal pada sistem Pilegda hanya bisa dicapai apabila sistem Pemilu legislatif daerah saat ini diganti dengan sistem Pemilu legislatif daerah yang semidistrik, yaitu satu Dapil hanya satu kecamatan dan model formula pemilihan berdasarkan asas pluralitas; dan juga sistem ini harus didukung dengan penguatan kelembagaan dan program kerja Parpol dalam kaderisasi, serta penggunaan dan pemafaatan teknologi informasi pada setiap tahapan Pilegda, sehingga pelaksanaan sistem Pilegda dapat berdampak pada meningkatkan hubungan keterwakilan politik masyarakat terhadap legislatornya, dan kinerja legislator itu sendiri sebagai wakil rakyat daerah di DPRD Kabupaten/kota.

Secara politik, dengan tingginya tingkat perwakilan politik dengan model hubungan utusan (delegate) maka dapat kita usulkan untuk Pilkada dapat dilakukan dengan pemilihan oleh DPRD saja, walaupun hal ini masih perlu kajian yang lebih mendalam. Sistem Pemilu legislatif daerah saat ini belum harmoni dengan sistem 
pemerintahan daerah, sebab sistem Pilegda seharusnya menggunakan model semidistrik. Oleh karena itu, perubahan sistem Pilegda dari proporsional terbuka ke sistem semi-distrik harus dilakukan dengan melakukan perubahan tiga hal, yaitu: pertama, melakukan pengurangan wilayah Dapil hanya sebatas wilayah satu kecamatan saja; kedua, melakukan formula perhitungan suara dengan menggunakan asas pluralitas; dan ketiga, melakukan penguatan fungsi organisasi dan pengkaderan Parpol.

Kemudian, dengan adanya perubahan diatas, maka harus didukung pula dengan penyelenggaraan Pilegda yang berkualitas (profesional, jujur, dan adil) dan berintegritas, sehingga mampu melahirkan para legislator daerah yang memiliki tingkat keterwakilan politik yang baik terhadap konstituennya, serta sekaligus mampu memberikan efektivitas dalam penyelenggaraan pemerintahan daerah.

Selanjutnya, penyatuan regulasi yang terintegrasi antara sistem Pemda dan Sistem Pilegda serta Sistem Pemilu kepala daerah merupakan suatu keharusan agar tercipta harmonisasi sistem yang berakibat pada kinerja Pemda yang lebih efektif lagi. Hal ini juga harus di dukung oleh regulasi atau peraturan kementerian dalam negeri (Permendagri), yang saling menunjang dan mendukung terciptanya keselarasan aturan untuk peningkatan kinerja, baik oleh Pemerintah daerah maupun oleh DPRD, sehingga efektifitas Pemda dapat tercapai dengan baik.

\section{Kesimpulan}

Sistem Pemilu yang digunakan saat ini perlu dilakukan perubahan yang cukup mendasar untuk memenuhi keseimbangan sistem Pemilu legislatif daerah dengan sistem pemerintahan daerah yang berpedoman pada tingkat perwakilan politik di DPRD. Di mana sistem pemilihan umum legislatif daerah memiliki tingkat perwakilan politik masyarakat yang tinggi dengan konstituennya semi-distrik. Dengan kata lain, kondisi ideal pada sistem Pilegda hanya bisa dicapai apabila sistem Pemilu legislatif daerah diganti dengan sistem Pemilu legislatif daerah yang semi-distrik, yaitu: pertama, satu Dapil hanya satu kecamatan; kedua, model formula pemilihan berdasarkan asas pluralitas; dan ketiga, sistem ini harus didukung dengan penguatan kelembagaan dan program kerja Parpol dalam kaderisasi, termasuk penggunaan dan pemafaatan teknologi informasi pada setiap tahapan Pilegda, sehingga pelaksanaan sistem Pilegda dapat 
berdampak pada meningkatkan hubungan keterwakilan politik masyarakat terhadap legislatornya, dan kinerja legislator itu sendiri sebagai wakil rakyat daerah di DPRD Kabupaten/kota.

Kemudian, peneliti juga mendapatkan simpulan tentang konsep sistem pemilihan umum legislatif daerah yang memiliki harmonisasi dengan sistem pemerintahan daerah dalam perspektif politik, bahwa dalam tinjauan politis, sistem Pemilu legislatif daerah saat ini belum harmoni dengan sistem pemerintahan daerah, sebab sistem Pilegda belum menggunakan model semi-distrik. Oleh karena itu, perubahan sistem Pilegda dari proporsional terbuka ke sistem semi-distrik harus dilaksanakan untuk mencapai harmoni secara sistem. Korelasi hubungan yang harmoni antara sistem Pilegda dan sistem pemerintahan daerah, ditinjau dari efektivitas pemerintahan daerah dalam kerangka model otonomi daerah dapat tercapai dengan baik; apabila sistem Pemilu legislatif daerah dapat meningkatkan model perwakilan politik yang bersifat utusan atau "delegate". Model ini, dapat terwujud apabila sistem Pilegda yang digunakan adalah sistem semi-distrik; di mana sistem ini sangat menjamin tingkat keterwakilan politik legislator hanya kepada konstituennya sangat tinggi; namun memang terjadi pelemahan terhadap perwakilan/kepentingan partai politik.

Pada akhirnya, peneliti berkeyakinan bahwa sistem Pemilu legislatif daerah yang menggunakan model semi-distrik, dengan didukung penyelenggaraan yang berkualitas, berintegritas dan profesional, serta jujur dan adil; akan mampu melahirkan para legislator daerah yang memiliki tingkat keterwakilan politik yang baik terhadap konstituennya dan Parpolnya; dan sekaligus mampu memberikan efektivitas dalam penyelenggaraan pemerintahan daerah. 
M. Fadhillah Harnawansyah

\section{BLIBIOGRAFI}

Achmad, A. F., \& Rudianto, D. (2012). Tata kelola bernegara dalam perspektif politik. Golden Terayon Press.

Duverger, M., \& Stevenson, J. (1955). Droit constitutionnel et institutions politiques. Presses universitaires de France.

Haris, S. (2005). Pemilu langsung di tengah oligarki partai: proses nominasi dan seleksi calon legislatif Pemilu 2004. Gramedia Pustaka Utama.

Misbak, M. (2018). Implementasi Kebijakan Program Prioritas Legalisasi Aset Sertifikat Tanah Bagi Nelayan di Kota Cirebon. Syntax Literate; Jurnal Ilmiah Indonesia, 3(1), 60-74.

Riwanto, A. (2016). Hukum partai politik dan hukum pemilu di Indonesia. Pengaruh Terhadap Penyelenggaraan Pemilu Berkualitas Dan Sistem Pemerintahan Presidensial Efektif, Thafa Media, Yogyakarta.

Wajong, J. (1975). Azas dan tujuan pemerintahan daerah. Djambatan. 